\title{
Soil carbon controlled by plant, microorganism and mineralogy interactions
}

\author{
C. Merino ${ }^{1}$, P. Nannipieri ${ }^{2}$, F. Matus ${ }^{3,4^{*}}$

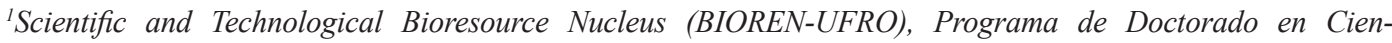 \\ cias de Recursos Naturales, Universidad de la Frontera, Temuco, Chile. ${ }^{2}$ Department of Agrifood and En- \\ vironmental Sciences, University of Firenze. ${ }^{3}$ Departamento de Ciencias Químicas y Recursos Naturales, \\ Universidad de La Frontera, Temuco, Chile. ${ }^{4}$ Scientific and Technological Bioresource Nucleus (BIOREN- \\ UFRO), Universidad de La Frontera, Temuco, Chile. *Corresponding author: francisco.matus@ufrontera.cl
}

\begin{abstract}
Rhizosphere, a thin area of soil surrounding roots receiving carbon (C) exudation from plants, represents a site of intense competition for available $\mathrm{C}$ and nutrient between surface-reactive particles and soil microorganisms. This competition can reduce the amount of available $\mathrm{C}$ to a critical level, it becomes limiting for microbial growth and soil organic matter decomposition. On the other hand, acceleration or retardation of decomposition of soil organic $\mathrm{C}$ caused by root activity is termed rhizosphere priming effect (RPE). This effect has been increasingly recognized to play a crucial role on native $\mathrm{C}$ destabilization as is influenced by fresh $\mathrm{C}$ availability, microbial activity and soil mineralogy such as crystallinity of clay minerals and Al-, Fe-oxides. Combining microbial ecology and soil mineral interactions, we can understand how soil characteristics and climate change can influence below ground competition and finally RPE. In this review, we focus on the competition for available $\mathrm{C}$ in soil, limiting our analyses to the interaction at rhizospheric space, where most processes between microorganisms and mineral phase occurs.
\end{abstract}

Keywords: Rhizosphere-priming effect, DOC, mineral interaction, carbon exudates

\section{Introduction}

Carbon input from plant to soil through root exudation is one of the major sources of available carbon (C) for microorganisms (Luo et al., 2014). Exudates from living roots stimulate a quick response of soil microbes with acceleration of native soil organic $\mathrm{C}$ mineralization, the so-called rhizosphere priming effect (RPE). Soil microbial activities are driven primarily by readily available or labile $\mathrm{C}$ provided by root turnover and rootexudates influxes (Dijkstra et al., 2013). Rhizosphere priming can also be affected by nutrient availability and substrate quality (Murphy et al., 2015). These interactive effects may be of particular relevance in understanding microbial growth and nutrient supply in response to increased atmospheric $\mathrm{CO}_{2}$ concentration and temperature. It is well established that increase 
in atmospheric $\mathrm{CO}_{2}$ increases photosynthesis, hence root exudation (Drigo et al., 2008). Competition between microorganisms and soil reactive particles for nutrient and dissolved organic C (DOC) is often neglected in the rhizosphere. Traditionally, it has been assumed that microorganisms can access quickly to labile $\mathrm{C}$ released into soil, although a number of biotic and abiotic processes can regulate the relative $\mathrm{C}$ in soil solution. In addition to microbial uptake, available $\mathrm{C}$ can decrease in the rhizosphere due to diffusion and convection process (Raynaud, 2010), and adsorption by soil particles with formation of soil aggregates (Albalasmeh and Ghezzehei, 2014). Weathered $\mathrm{Al}$ and $\mathrm{Fe}$ can complex DOC quickly in periods of time ranging from seconds to hours (Sparks, 2002). Microbial uptake of low molecular weight organic substances (LMWOS) (e.g., organic acids, amino acids and polysaccharides) from the soil solution takes place within minutes (Jones et al., 2004). In contrast, the half-life time of the same processes for $\mathrm{C}$ from LMWOS adsorbed onto mineral clay is longer - from several hours to months or even decades (van Hees et al., 2005).

We often assumed that microorganisms are better competitors than plant roots for nutrients (Kuzyakov and $\mathrm{Xu}, 2013$ ), because: i) they are involved in the mineralization process, ii) they present a great surface area: volume ratio and iii) they have rapid growth rates (Peng et al., 2008). Microorganisms have numerous strategies to increase their resource acquisition and competition for available $\mathrm{C}$ using biotic (e.g. extracellular enzymes release) and abiotic (e.g. redox and metal complexation) mechanisms (Hibbing et al., 2010). It is difficult to assess direct competition between microorganisms and minerals for soil $\mathrm{C}$ because of the multiple loops and pathways, through which $\mathrm{C}$ circulates amongst different $\mathrm{C}$ pools. Furthermore, abiotic factors such as soil $\mathrm{pH}$, amorphous $\mathrm{Fe}$ and $\mathrm{Al}$ oxides and hydroxides concentration (Kaiser and Guggenberger, 2000), and/or clay types (McDowell and Sharpley, 2003) contribute to protection of soil organic matter (SOM) from microbial decay (Jastrow et al., 2007). Consequently, the effects of available $\mathrm{C}$ on microbial activity in mineral soils at rhizosphere scale are poorly understood.

Here we discuss the impact of fast growing microorganisms competing for soluble $\mathrm{C}$ from rootexudates substrate in the rhizosphere on priming intensity. Root exudates can be released shortly after $\mathrm{C}$ fixation (15 minutes to hours) (Matus et al., 2014a) and soil mineralogy regulates labile $\mathrm{C}$ gradient concentration in the soil solution by adsorption processes and indirectly by pore size distribution.

The aim of this study is to discuss the biotic and abiotic factors controlling RPE and availability of $\mathrm{C}$ for soil microorganism assimilation. We have reviewed recent literature concerning RPE and chemical composition of SOM related to soil mineralogy operating mainly in temperate mineral soils. As a result, this review has three sections. First, we focus on available $\mathrm{C}$ and rhizosphere priming and its dependence on labile organic $\mathrm{C}$ compound in open interaction with soil surface minerals. In the second section, we discuss the interactions between mineralogy, plant and microorganism control on available $\mathrm{C}$ and the implications of these interactions on RPE. Finally, in the third section, RPE as an important mechanism of soil $\mathrm{C}$ transport into the subsoil is discussed.

\section{Available carbon and rhizophere priming}

Carbon input by plants into the soil is the primary source of SOM (Kuzyakov, 2002). This input and the availability of $\mathrm{C}$ induce fast turnover near the roots, because rhizosphere space is not limited by available C (Kuzyakov, 2002), but C is available in hot spots (Kuzyakov and Blagodatskaya, 2015). 
The RPE intensity is generally short lived changed by the transformation of $\mathrm{C}$ following the addition of moderate levels of carbonaceous and nitrogenous materials, including $\mathrm{C}$ rhizodeposition from roots (Kuzyakov, 2002). It is increasingly accepted that RPE intensity depends on the availability of fresh C energy and succession of soil microbial community (Fontaine et al., 2004). Root exudates consist of a complex mixture of $\mathrm{C}$ rich substrates, such as sugars (50-70\%), carboxylic acids (20-30\%) and amino acids (10-20\%) (de Graaff et al., 2010). Plant roots exert significant control over the flow rate of $\mathrm{C}(\mathrm{Lal}, 2004)$. Plants spend a large part of their photosynthetic $\mathrm{C}$ in the development and maintenance of the rhizosphere (de León-González et al., 2006). The fate of C exudates released into the soil solution depends on root fluxes, soil mineral adsorption, diffusion across soil pores, and microbial utilization (Kuzyakov et al., 2003). For example, and as previously mentioned, LMWOS are rapidly metabolized, whereas high molecular -weight compounds have to be hydrolysed to low molecular-weight products before they can be taken up by microbial cells (Weintraub et al., 2007). Neutral sugars can be quickly assimilated by microorganisms, because they are not electrically charged, with a half-life of only 20 to 40 minutes in soil (Fischer et al., 2010). While neutral sugars are fast metabolized, carboxylic acids (e.g. citric and malic acids) bearing charge, can rapidly be adsorbed by soil minerals (Dakora and Phillips, 2002). Half-life of organic acids and amino acids in the soil have been measured between $2 \mathrm{~h}$ and 12 h (Jones and Darrah, 1994; Jones, 1999). Organic acids, such as citrate, may be strongly sorbed into soil components (clay minerals) with the reduction of the relative mineralization rates (Bruun et al., 2010). Within 10 minutes, $99 \%$ and $83 \%$ of the added citrate was adsorbed by $\mathrm{Fe}$ oxides and kaolinite, respectively. Citrate decomposition was reduced for about $99 \%$ and $75 \%$ in the presence of Fe oxides and kaolinite, respectively (Jones and Edwards, 1998). Therefore, the organo-mineral complex formation is of a critical importance of controlling organic $\mathrm{C}$ availability to soil microorganisms (Lopez-Sangil and Rovira, 2013). Mineralization does not depend on the $\mathrm{C}$ input rate only, but also on the substrate quality, the initial N: C: P, and the chemical composition of the substrate. Microorganisms controls the available C by quickly uptake of free sugars from the soil, but represents a small proportion being immediately available in hot spots (Kuzyakov and Blagodatskaya, 2015). Most SOM is present in forms that are unavailable to microorganisms (Fontaine et al. 2003). The short-lived RPE in the rhizosphere related to the fast consumption of $\mathrm{C}$ during initial stage of mineralization is poorly understood.

In summary, it is important, therefore, to consider microorganisms and soil mineralogy competing for fresh organic $\mathrm{C}$ for microorganism assimilation. The interactions of these factors can accelerate (positive) or reduce (negative) the RPE by the decomposition of native soil organic matter (Dijkstra et al., 2009). The magnitude and direction of RPE are determined by the amount and type of $\mathrm{C}$ exudates released from the root, as well as intrinsic soil mineralogy. At the most basic level, understanding the general characteristics of $\mathrm{C}$ fluxes within the soils is difficult because of the diversity of microbial communities, the complexity of mineral soil interactions and the inherent environmental heterogeneity of soil ecosystems.

\section{Mineralogy, plant and microorganisms control the available carbon}

Very little is known about adsorption or desorption of different pools of organic components related to RPE 
in different soil types due to different mineralogy (Fischer et al., 2010). Rasmussen et al. (2006; 2007) studied the importance of the mineralogical composition on $\mathrm{C}$ mineralization in temperate rain forests. They found soil with amorphous clay (volcanic soils) showed a negative priming (Xue et al., 2005; Rasmussen et al., 2006) attributed to the strong adsorption of organic compounds, probably by ligand exchange reaction (Matus et al., 2104b).

Soil mineralogy controls the available $\mathrm{C}$ in the soil solution not only by adsorption processes, but indirectly limiting diffusion of oxygen and water due to the importance of soil minerals in the formation of soil aggregates (Six et al., 2004). This makes available $\mathrm{C}$ in soil less vulnerable to microbial degradation (Kalbitz and Kaiser, 2008). There is a physical occlusion of $\mathrm{C}$ in the interstitial space mesopores $(2-50 \mu \mathrm{m})$ in mineral soils (Zimmermann et al., 2009). The interactions between mineral phase and organic matter can lead to a stabilization of available $\mathrm{C}$ trapped or physically protected in soil micropores $(<2 \mu \mathrm{m})$ (Baldock and Skjemstad, 2000). Apart from physical protection, as it was already mentioned, the intermolecular interactions between $\mathrm{C}$ and surface of clay particles and oxides of $\mathrm{Fe}$ and Al play an important role too (Matus et al., 2008). Amorphous $\mathrm{Al}$ and $\mathrm{Fe}$ oxides are the most reactive components of acidic and neutral soils (Matus et al., 2014b) and have a key function in chemical speciation, bioavailability of nutrients and detoxification (Olaniran et al., 2013). The role of $\mathrm{Al}$ and its effects on water extractable organic matter was evaluated in two old growth temperate rain forests (Merino et al., personal communication). Mineralization of soluble $\mathrm{C}$ was not affected by increasing $\mathrm{Al}$ addition rate and potential toxicity by $\mathrm{Al}^{3+}$ was not observed after 15 days of incubation experiment. This study suggests that $\mathrm{Al}^{3+}$ is toxic when $\mathrm{Al}: \mathrm{C}$ ratio $<0.12$ (Scheel et al., 2008). However, the effects of $\mathrm{Al}$ on natural DOC degradation in mineral soils of forests are poorly understood and it is necessary to study Al-humus formation and $\mathrm{Al}^{3+}$ detoxification for their effect on $\mathrm{C}$ availability. Indeed, the quantitative information on the degradation of available $\mathrm{C}$ has been obtained by studying the decomposition of LMWOS differing for the position of labelled C (Apostel et al., 2015). Alanine ${ }^{14} \mathrm{C}$ labelled in $\mathrm{C}-1, \mathrm{C}-2$ and $\mathrm{C}-3$ position was adsorbed by iron oxides, clay minerals (2:1 and 1:1) and activated charcoal. The highest sorption capacity resulted in the low $\mathrm{C}$ utilization by soil microbes. Mineralization of alanine peaked within the first $5 \mathrm{~h}$ and it was always the highest for $\mathrm{C}-1$ position (- $\mathrm{COOH}$ group), whereas $\mathrm{C}-2$ and $\mathrm{C}-3$ mineralization exceeded the mineralization rate of $\mathrm{C}^{-1}$ after $10-50 \mathrm{~h}$. The metabolic pathways, i.e. glycolysis depended on C oxidation and the Krebs cycle of sorbed Alanine at initial stage of decomposition (Dippold et $a l ., 2014)$. This raises the question whether these low molecular weight compounds are used by the overall soil microflora or by different microbial groups. On the other hand, plants may alter the dynamics of microbial $\mathrm{C}$ fluxes and $\mathrm{C}$ use efficiency by balancing the catabolic and anabolic metabolism in the rhizosphere. Carbon utilization efficiency by soil microbes was 1.5 times higher in root-free soil than in the rhizosphere soil (Blagodatskaya et al., 2014).

Extracellular soil enzyme activities play a key role in RPE by breaking down native organic matter (depolymerization, e.g., peroxydase) producing soluble simple compounds for microbial assimilation (Sinsabaugh et al., 2009; Sinsabaugh et al., 2010; Nannipieri et al., 2012). Once organic $\mathrm{C}$ is inside the microbial cell, it can be mineralized to $\mathrm{CO}_{2}$ with the production of ATP (Meir et al., 2013). Under aerobic conditions, the oxidative metabolism of organic compound produces more energy, ATP and $\mathrm{CO}_{2}$ than the anaerobic metabolism (Zhu et al., 2014).The literature on soil enzymology is extensive (Nannipieri et al., 2012) as well as the enzyme-organo-mineral interaction such as thr enzyme adsorption to minerals (Nannipieri 
et al., 1996) and enzyme-clay interaction (Gianfreda and Bollag, 1994), but the role of enzymes-organomineral on RPE is poorly understood. Some priming studies have looked directly at enzyme activities, but the results have been contradictory (Table 1). .

If biotic processes are modified by soil mineralogy, the latter also plays a control on $\mathrm{C}$ turnover with an important catalytic role in accelerating abiotic polymerization of phenolic compounds and amino acids to the formation of humic substances. Silicates and $\mathrm{Fe}$ oxides can catalyze redox reactions and promote SOM oxidation (Derry et al., 2005). Besides, enzymelike reactions can affect $\mathrm{C}$ turnover in soil (Ruggiero et al., 1996). For instance, humid tropical forests have the fastest rates of organic matter decomposition, which often coincides with fluctuating oxygen $\left(\mathrm{O}_{2}\right)$ availability in surface soils. Alike tropical soils, humid temperate rain forest soils are typically rich in short-range ordered iron oxide $\mathrm{Fe}^{3+}$ minerals. Those soils show fluctuating oxygen availability over scales of hours to weeks where $\mathrm{Fe}^{3+}$ is reduced to ferrous $\mathrm{Fe}^{2+}$ and subsequently re-oxidized via biotic or abiotic reactions (Dubinsky et al., 2010; Hall et al., 2012). This mechanism stimulates organic matter decomposition via: organic matter oxidation, likely driven by reactive oxygen species; and acidification (Hall and Silver, 2013). Dissimilatory Fe reducing bacteria are well known to oxidize soil organic matter and can account for the majority of $\mathrm{C}$ oxidation under anaerobic conditions (Dubinsky et al., 2010). Abiotic processes have been underestimated across soil profile and should be addressed in future research.

\section{Rhizosphere priming effect and molecular transport to the subsoil}

Complexation of labile compounds with metal such as $\mathrm{Al}$ and $\mathrm{Fe}$ Oxides provides a direct mechanism for translocation of organic $\mathrm{C}$ within the soil profile (Kaiser and Kalbitz, 2012).

Sorption by mineral surfaces can protect simple molecules from microbial degradation to some extent (van Hees et al., 2002; Jones and Edwards (1998) compared degradation and sorption of citrate and glucose, and similar studies by Jones and Hodge (1999) were carried out for glutamate, glycine and lysine. Results from both investigations indicated that the reduction of the availability of $\mathrm{C}$ for microbial assimilation depended on the type of root exudates and the mineral type. Adsorption of simple molecules onto clay surfaces is almost irreversible, that means short term mineralization of these organic acids while they are available (Boudot, 1992).

The studies of Jones (1999); Jones and Hodge (1999): and Owen and Jones (2001) have shown a rapid mineralization of free amino acids (glycine, glutamate and lysine) by microflora from soil solution.

Preferential $\mathrm{C}$ uses by soil microorganisms of these compounds can lead to a change in the SOM turnover induced by fresh C input (Sparling et al., 1982) from not exudate. We have already mentioned that Rasmussen et al. (2007; 2006) studies in which mineralogical composition of surface forest soil induced a negative priming because of amorphous minerals. Besides, the chemical interaction of SOM, Al- and Fe-oxides can protect SOM against microbial degradation, since it promotes SOM-humus complexes and stable soil aggregation thereby providing physical protection of SOM aggregation (Panichini et al., 2012).

It has been long hypothesised that non-crystalline minerals like allophane as been formed in situ, rather than by translocation (Dahlgren et al., 2004). However recently, the transport of mineral-SOM complexes to deeper soil has been reported by conversion of tropical forest into grassland (Osher et al., 2003). In high precipitation regions, $\mathrm{C}$ losses from the soil appear to occur via downward transport, either as colloids or in 
solution. There are almost no studies that address the organic translocation in the subsoil. Kaiser and Kalbitz (2012) indicate that sorbed organic compounds can be desorbed because of protective site saturation. This effect is due to complex reactions of $\mathrm{Al}$ with soil organic $\mathrm{C}$ from the soil solution and the subsequent precipitation of insoluble complexes of Al-SOM (Rasmussen et al., 2006). It is needed empirical evidence showing the importance of labile compounds available for microorganism and transport. This is important for determining the type od organic matter that is sorbed under specific conditions.

Table 1. Organic compounds and enzymes identified in root exudates used in studies of priming effect.

\begin{tabular}{|c|c|c|c|}
\hline $\begin{array}{c}\text { Organic } \\
\text { compounds }\end{array}$ & $\begin{array}{l}\text { C-input } \\
\mathrm{g} \mathrm{C} \mathrm{kg}^{-1} \text { soil }\end{array}$ & Ezyme activity & References \\
\hline Citric acid & $0.3-0.6$ & $\begin{array}{l}\text { Phosphomonoesterase }^{\mathrm{a}} \text {, } \\
\text { Urease, phosphodiesterase }\end{array}$ & $\begin{array}{l}\text { Lundström et al. (2000); Clemens et al. } \\
\text { (2002); Renella et al. (2007); Luo et al. } \\
\text { (2014) }\end{array}$ \\
\hline Oxalic acid & 0.6 & Phosphomonoesterase & $\begin{array}{l}\text { Lundström et al. (2000); Zheng et al. } \\
\text { (1998); Yang et al. (2000); Luo et al. } \\
\text { (2014) }\end{array}$ \\
\hline Acetate & 8 & $\begin{array}{l}\beta \text {-glucosidase, } \\
\text { phosphomonoesterase }\end{array}$ & Allison et al. (2005); \\
\hline Malic acid & $6-41$ & & $\begin{array}{l}\text { Clemens et al. (2002); Chowdhury et al. } \\
\text { (2014); Rukshana et al. (2012) }\end{array}$ \\
\hline Glucose & $0.6-25$ & $\begin{array}{l}\text { Phosphomonoesterase, urease, } \\
\text { casein-hydrolyzingenzymes }\end{array}$ & $\begin{array}{l}\text { Luo et al. (2014); Strickland et al. } \\
\text { (2012); Nannipieri et al. (1983) }\end{array}$ \\
\hline
\end{tabular}

${ }^{a}$ We have replaced the term acid or alkaline phosphatase by "phosphomonoesterase", since the term phosphatase includes several enzymes in biochemistry e.g. phosphomonoesterases, phosdiesterases, etc (Nannipieri et al., 2011). 


\section{Concluding remarks}

. Root exudates into the soil solution can be: 1) consumed by soil microorganism and degraded, 2) mineralized abiotically by mineral catalytic effect or, 3 ) leached from the soil profile, 4) sorbed to the solid phase or even taken up by plants.

.The low molecular weight of organic substances assimilated directly from soil solution might affect the intensity of RPE, but this process depends on spatial heterogeneity of the rhizosphere.

. Available $\mathrm{C}$ for microflora consumption depends on the mineral composition and the type of exudates, and their relative concentrations.

- The microbial interactions with the mineral phase can affect reactions and the process of soil C. Organic $\mathrm{C}$ derived from microbial activity and root exudates is probably the most mobile and bioavailable fraction of $\mathrm{C}$ in the rhizosphere. The retention and mobility of organic compounds depend on soil properties and can affect the availability of soluble $\mathrm{C}$ for soil microbes.

. The effects of root exudates and DOC on RPE across the soil profile need to be further investigated, because the primed compounds may ocurr in hotspots at root scale.

- Aluminium humus-complex formation needs further attention because Al may be toxic for soil microorganisms, but also it can detoxify the soil solution and enhance $\mathrm{C}$ assimilation.

- The saturation of the C-storage capacity of soil, mainly due to organo-mineral interactions, can affect the transport of DOC to deeper soil horizons.

- Rhizosphere priming effects may occur, but it is unknown whether it affects SOM mineralization across the soil profile. There is evidence that RPE on the topsoil SOM of Volcanic soils under forest cover may account for approximately $1 / 5$ of the annual $\mathrm{CO}_{2}$ evolution from the soil.

\section{Future directions}

. The hypothesis that RPE is driven by low molecular weight organic substances from root exudates requires further research. Based on current knowledge, research regarding SOM competition between soil microflora and mineral phase over time also needs to be addressed in future studies.

. The hypothesis that DOC is the most susceptible to stabilize through different organo-mineral interactions through the soil profile requires further studies.

. We have hypothesised that SOM mineralization due to RPE may be important across the soil profile. This is supported by new conceptual models explaining colloidal transports in soil with different mineralogy.

- The composition of microbial communities during RPE needs to be monitored in soil with different mineralogy. In high reactive soil e.g. allophanic, RPE will be less intense than soils with crystalline clays.

\section{Acknowledgements}

The authors thank to CONICYT-Chile for their financial contributions through FONDECYT Projects 1130193 and Insertion Project of Advanced Human Capital in the Chilean Privet Sector, 781301003.

\section{References}

Albalasmeh, A., Ghezzehei, T. 2014. Interplay between soil drying and root exudation in rhizosheath development. Plant Soil. 374, 739-751.

Allison, S.D. 2005. Cheaters, diffusion, and nutrients constrain decomposition by microbial enzymes in spatially structured environments. Ecol. Lett. 8, 626-635.

Apostel, C., Dippold, M., Kuzyakov, Y. 2015. Biochemistry of hexose and pentose transformations in soil analyzed by position- 
specific labeling and ${ }^{13}$ C-PLFA. Soil Biol. Biochem. 80, 199-208.

Baldock, J.A., Skjemstad, J.O. 2000. Role of the soil matrix and minerals in protecting natural organic materials against biological attack. Org. Geochem. 31, 697-710.

Basile-Doelsch, I., Amundson. R., Stone, W.E.E., Borschneck D., Bottero, J.Y., Moustier, S., Masin. F., Colin, F. 2007. Mineral control of carbon pools in a volcanic soil horizon. Geoderma. 137, 477-489.

Blagodatskaya, E. , Jomiakov, N. , Myachina, O. , Bogomolova, I. , Blagodatsky, S., Kuzyakov, Y. 2014. Interactions affect microbial sources cellulose induced priming. Soil Biol. Biochem. 74, 39 - 49.

Boudot, J-P. 1992. Relative efficiency of complexed aluminum noncrystalline $\mathrm{Al}$ hydroxide, allophane and imogolite in retarding the biodegradation of citric acid. Geoderma. 52, 29-39.

Bruun, T.B., Elberling, B., Christensen, B.T. 2010. Lability of soil organic carbon in tropical soils with different clay minerals. Soil Biol. Biochem. 42, 888-895.

Chowdhury, S., Farrell, M., Bolan, N.S. 2014. Priming of soil organic carbon by malic acid addition is differentially affected by nutrient availability. Soil Biol. Biochem. 77, 158-169.

Clemens, S., Palmgren, M., Kramer, U. 2002. A long way ahead: understanding and engineering plant metal accumulation. Trends. Plant Sci. 7, 309315.

Dahlgren, R.A., Saigusa, M., Ugolini, F.C. 2004. The nature, properties and management of volcanic soils. Adv. Agronomy. 82, 182.
Dakora, F., Phillips, D. 2002. Root exudates as mediators of mineral acquisition in low-nutrient environments. Plant Soil. 245, 35-47.

De Graaff, M.A., Classen, A.T., Castro, H.F., Schadt, C.W. 2010. Labile soil carbon inputs mediate the soil microbial community composition and plant residue decomposition rates. New Phytologist. 188, 1055-1064.

De León-González, F., Celada-Tornel, E., HidalgoMoreno, C.I., Etchevers-Barra, J.D., Gutiérrez Castorena, M.C., Flores-Macías, A. 2006. Rootsoil adhesion as affected by crop species in a volcanic sandy soil of Mexico. Soil Till. Res. 90, $77-83$.

Derry, L.A., Kurtz, A.C., Ziegler, K., Chadwick, O.A. 2005. Biological control of terrestrial silica cycling and export fluxes to watersheds. Nature. 433, 728-731.

Dijkstra, F.A., Bader, N.E., Johnson, D.W., Cheng, W. 2009. Does accelerated soil organic matter decomposition in the presence of plants increase plant N availability?. Soil Biol. Biochem. 41, 1080-1087.

Dijkstra, F.A., Carrillo, Y., Pendall, E., Morgan, J.A. 2013. Rhizosphere priming: a nutrient perspective. Frontiers in Microbiology. 4, 216.

Dippold, M., Biryukov, M., Kuzyakov, Y. 2014. Sorption affects amino acid pathways in soil: Implications from position-specific labeling of alanine. Soil Biol. Biochem. 72, 180-192.

Drigo, B., Kowalchuk, G.A., Van Veen, J.A. 2008. Climate change goes underground: effects of elevated atmospheric $\mathrm{CO}_{2}$ on microbial community structure, and activities in the rhizosphere. Biol. Fert.Soils. 44, 667-679. 
Dubinsky, E.A., Silver, W.L., Firestone, M.K. 2010. Tropical forest soil microbial communities couple iron and carbon biogeochemistry. Ecology. 91, 2604-2612.

Fischer, H., Ingwersen, J., Kuzyakov, Y. 2010. Microbial uptake of low-molecular-weight organic substances out-competes sorption in soil. Eur. J. Soil Sci. 61, 504-513.

Fontaine, S., Mariotti, A., Abbadie, L. 2003. The priming effect of organic matter: a question of microbial competition?. Soil Biol. Biochem. 35, 837-843.

Fontaine, S., Bardoux, G., Abbadie, L., Mariotti, A. 2004. Carbon input to soil may decrease soil carbon content. Ecol. Lett. 7, 314-320.

Gianfreda, L., Bollag, J-M. 1994. Effect of Soils on the behavior of immobilized enzymes, Soil Sci. Amer. J. 58, 1672- 1681.

Hall, S.J., McDowell, W.H., Silver, W.L. 2012. When wet gets wetter: decoupling of moisture, redox biogeochemistry, and greenhouse gas fluxes in a humid tropical forest soil. Ecosystems 16, 576589.

Hall, S.J., Silver, W.L. 2013. Iron oxidation stimulates organic matter decomposition in humid tropical forest soils. Global Change Biol. 19, 2804-2819.

Hibbing, M.E., Fuqua, C., Parsek, MR., Peterson, S.B. 2010. Bacterial competition: surviving and thriving in the microbial jungle. Nature reviews. Microbiology. 8, 15-25.

Jastrow, J., Amonette, J., Bailey, V. 2007. Mechanisms controlling soil carbon turnover and their potential application for enhancing carbon sequestration. Climatic Change. 80, 5-23.

Jones, D.L. 1999. Amino acid biodegradation and its potential effects on organic nitrogen capture by plants. Soil Biol. Biochem. 31, 613-622.
Jones, D.L., Darrah, P.R. 1994. Amino-acid influx at the soil-root interface of Zea mays L. and its implications in the rhizosphere. Plant Soil. 163, $1-12$.

Jones, D.L., Edwards, A.C. 1998. Influence of sorption on the biological utilization of two simple carbon substrates. Soil Biol. Biochem. 30, 1895-1902.

Jones, D.L., Hodge, A. 1999. Biodegradation kinetics and sorption reactions of three differently charged amino acids in soil and their effects on plant organic nitrogen availability. Soil Biol. Biochem. 31, 1331-1342.

Jones, D.L., Hodge, A., Kuzyakov, Y. 2004. Plant and mycorrhizal regulation of rhizodeposition. New Phytologist. 163, 459-480.

Kalbitz, K., Kaiser, K. 2008. Contribution of dissolved organic matter to carbon storage in forest mineral soils. J. Plant Nutr. Soil Sc. 171, 52-60.

Kaiser, K., Guggenberger, G. 2000. The role of DOM sorption to mineral surfaces in the preservation of organic matter in soils. Org. Geochem. 31, 711-725.

Kaiser, K., Kalbitz, K. 2012. Cycling downwards : Dissolved organic matter in soils. Soil Biol. Biochem. 52, 29-32.

Kuzyakov, Y. 2002. Review: Factors affecting rhizosphere priming effects. J. Plant Nutr. Soil Sc. $165,382$.

Kuzyakov, Y., Raskatov, A., Kaupenjohann, M. 2003. Turnover and distribution of root exudates of Zea mays. Plant Soil. 254, 317-327.

Kuzyakov, Y., Xu, X. 2013. Competition between roots and microorganisms for nitrogen: mechanisms and ecological relevance. New Phytol. 198, 656669.

Lal, R. 2004. Soil carbon sequestration to mitigate climate change. Geoderma. 123, 1-22. 
Lopez-Sangil, L., Rovira, P. 2013. Sequential chemical extractions of the mineral-associated soil organic matter: An integrated approach for the fractionation of organo-mineral complexes. Soil Biol. Biochem. 62, 57-67.

Lundström, U.S., Van Breemen, N., Bain, D.C., Van Hees, P.A.W., Giesler, R., Gustafsson, J.P., Ilvesniemi, H., Karltun, E., Melkerud, P.A., Olsson, M., Riise, G., Wahlberg, O., Bergelin, A., Bishop, K., Finlay, R., Jongmans, A.G., Magnusson, T., Mannerkoski, H., Nordgren, A., Nyberg, L., Starr, M., Strand, L.T. 2000. Advances in understanding the podzolization process resulting from a multidisciplinary study of three coniferous forest soils in the Nordic Countries. Geoderma. 94, 335-353.

Luo, Y., Xueyong, Z., Olof, A., Yangchun, Z., Wenda, H. 2014. Artificial root exudates and soil organic carbon mineralization in a degraded sandy grassland in northern China. J. Arid Land. 6, 423-431.

Maire, V., Alvarez, G., Colombet, J., Comby, A., Despinasse, R., Dubreucq, E. 2013. An unknown oxidative metabolism substantially contributes to soil $\mathrm{CO}_{2}$ emissions. Biogeosciences. 10, 11551167.

Matus, F., Garrido, E., Sepúlveda, N., Cárcamo, I., Panichini, M., Zagal, E. 2008. Relationship between extractable $\mathrm{Al}$ and organic $\mathrm{C}$ in volcanic soils of Chile. Geoderma. 148, 180-188.

Matus, F., Monreal, C., Lefebvre, M. Wu, S., Desjardins, R. DeRosa, M. 2014a. Producing isotopically enriched plant, soil solution and rhizosphere soil materials over a few hours Comm. Soil Sci. Plant Anal. 45 865-880.

Matus, F., Rumpel, C., Neculman, R., Panichini, M., Mora, M.L.2014b. Soil carbon storage and stabilisation in andic soils : A review. Catena. 120, 102-110.
McDowell, R.W., Sharpley, A.N. 2003. Phosphorus solubility and release kinetics as a function of soil test $\mathrm{P}$ concentration. Geoderma. 112, 143-154.

Murphy, C.J., Baggs, E., Morley, N., Muro, D., Paterson, E. 2015. Rhizosphere priming can promote mobilisation of $\mathrm{N}$-rich compounds from soil organic matter. Soil Biol. Biochem. 81, 236243.

Nannipieri, P., Muccini, L., Ciardi, C. 1983. Microbial biomass and enzyme activities: production and persistence. Soil Biol. Biochem. 15, 679-685.

Nannipieri, P., Sastre. J., Landi, L., Lobo, M.C., Pietramellara, G. 1996. Determination of extracellular neutral phosphomonoeterase activity in soil. Soil Biol. Biochem. 28, 107-112.

Nannipieri, P., Giagnoni, L., Renella, G., Puglisi, E., Ceccanti, B., Masciandaro, G., Fornasier, F., Moscatelli, M.C., Marinari, S. 2012. Soil enzymology: classical and molecular approaches. Biol. Fert. Soils. 48, 743-762.

Olaniran, A.O., Balgobind, A., Pillay, B. 2013. Bioavailability of Heavy Metals in Soil: Impact on Microbial Biodegradation of Organic Compounds and Possible Improvement Strategies. Int. J. Mol. Sci. 14, 10197-10228.

Osher, L.J., Matson, P.A., Amundson, R. 2003. Effect of land use change on soil carbon in Hawaii. Biogeochemistry. 5, 213-222.

Owen, A.G., Jones, D.L. 2001. Competition for amino acids between wheat roots and rhizosphere microorganisms and the role of amino acids in plant $\mathrm{N}$ acquisition. Soil Biol. Biochem. 33, 651657.

Panichini, M., Matus, F., Mora, M.L., Godoy, R., Bolan, N.S., Rumpel, C., Borie, F. 2012. Carbon distribution in top- and subsoil horizons of two contrasting Andisols under pasture or forest. Eur. J. Soil Sci. 63, 616-624. 
Peng, X., Huaiyang, Z., Cancion, T., Huiqiang, Y., Lei, J., Zijun, W. 2008. Early-stage mineralization of hydrothermal tubeworms: New insights into the role of microorganisms in the process of mineralization. Chinese Sci. Bull. 53, 251-261.

Rasmussen, C., Southard, R.J., Horwath, W.R. 2006. Mineral control of organic carbon mineralization in a range of temperate conifer forest soils. Global Change Biol. 12, 834-847.

Rasmussen, C., Southard, R.J., Horwath, W.R., 2007. Soil Mineralogy Affects Conifer Forest Soil Carbon Source Utilization and Microbial Priming. Soil Sci. Soc. Am. J. 71, 1141.

Raynaud, X. 2010. Soil properties are key determinants for the development of exudate gradients in a rhizosphere simulation model. Soil Biol. Biochem. 42, 210-219.

Renella, G., Szukics, U., Landi, L., Nannipieri, P. 2007. Quantitative assessment of hydrolase production and persistence in soil. Biol. Fertil. Soils. 44, 321-329.

Ruggiero, P., Dec, J., Bollag, J-M. 1996. Soil as a catalytic system. In Stotzky G and Bolag J-M (Eds) Marcel Dekker, New York, 79-122.

Rukshana, F., Butterly, C.R., Baldock, J.A., Xu, J.M., Tang, C. 2012. Model organic compounds differ in priming effects on alkalinity release in soils through carbon and nitrogen mineralisation.Soil Biol. Biochem. 51, 35-43.

Scheel, T., Jansen, B., van Wijk, A.J., Verstraten, J.M., Kalbitz, K. 2008. Stabilization of dissolved organic matter by aluminium: a toxic effect or stabilization through precipitation?. Eur. J. Soil Sci. $59,1122-1132$.

Sinsabaugh, R.L., Hill, B. H., Follstad Shah, J. J. 2009. Ecoenzymatic stoichiometry of microbial organic nutrient acquisition in soil and sediment. Nature. 462, 795-798.
Sinsabaugh, R.L., Follstad, Shah, J.J. 2010. Integrating resource utilization and temperature in metabolic scaling of riverine bacterial production. Ecology. 91, 1455-1465.

Six, J., Bossuyt, H., Degryze, S., Denef, K. 2004. A history of research on the link between (micro) aggregates, soil biota, and soil organic matter dynamics. Soil Till. Res. 79, 7-31.

Sparks, D.L. 2002. Environmental Soil Chemistry. 2. Academic Press, New York, 352.

Sparling, G.P., Cheshire, M.V., Mundie, C.M. 1982. Effect of barley plants on the decomposition of ${ }^{14} \mathrm{C}$-labelled soil organic matter. Soil Sci. Soc. Am. J. 33, 89-100.

Strickland, M., Osburn, E., Lauber, C., Fierer, N., Bradford, MA. 2009. Litter quality is in the eyeof the beholder: initial decomposition rates a function of inoculum characteristics. Functional Ecology. 23, 627-636.

Van Hees, P.A.W.,Jones, D.L., Jentschke, G., Godbold, D.L. 2005. Organic acid concentrations in soil solution: effects of young coniferous trees and ectomycorrhizal fungi. Soil Biol. Biochem. 37, 771-776.

Van Hees, P.A.W., Jones, D.L. Godbold, D.L. 2002. Biodegradation of low molecular weight organic acids in coniferous forest podzolic soils. Soil Biol. Biochem. 34, 1261-1272.

Weintraub, M., Scott-Denton L., Schmidt, SK., Monson, R.K. 2007. The effects of tree rhizodeposition on soil exoenzyme activity, dissolved organic carbon, and nutrient availability in a subalpine forest ecosystem. Oecologia. 154, 327-338.

Xue, J.M., Sands, R., Clinton, P.W.,Payn, T.W., Skinner, M.F. 2005. Priming effect of biuret addition on native soil $\mathrm{N}$ mineralisation under laboratory conditions. Soil Biol. Biochem. 37, 959-1961. 
Yang, Y.H., Yao, J., Hu, S. 2000. Effects of agricultural chemicals on DNA sequence diversity of soil microbial community: A study with RAPD marker. Microb.Ecol. 39, 72-79.

Zhu, B., Gutknecht, J., Herman, D., Keck, D., Firestone, M., Cheng, W. 2014. Rhizosphere priming effects on soil carbon and nitrogen mineralization. Soil Biol. Biochem. 76, 183-192.
Zimmermann, M., Meir, P., Bird, M., Malhi, Y., Ccahuana, A. 2009. Litter contribution to diurnal and annual soil respiration in a tropical montane cloud forest. Soil Biol. Biochem. 41, 1338-1340.

Zheng, S.J., Ma, J.F., Matsumoto, H. 1998. High aluminium resistance in buckwheat. I. Al-induced specific secretion of oxalic acid from root tips. Plant Physiol. 117, 745-751. 